\title{
Factors Affecting Audit Quality: The Moderating Effect of Dysfunctional Behavior
}

\author{
Aldi Rivaldi ${ }^{1}$, Khoirul Aswar ${ }^{1, *}$, Taufeni Taufik ${ }^{2}$, Andreas $^{2}$, Eka Hariyani $^{2}$ \\ ${ }^{1}$ Department of Accountancy, Faculty of Economics and Business, Universitas Pembangunan Nasional Veteran Jakarta, Indonesia \\ ${ }^{2}$ Department of Accountancy, Faculty of Economics and Business, Universitas Riau, Indonesia
}

Received November 8, 2021; Revised December 18, 2021; Accepted January 16, 2022

\section{Cite This Paper in the following Citation Styles}

(a): [1] Aldi Rivaldi, Khoirul Aswar, Taufeni Taufik, Andreas, Eka Hariyani, "Factors Affecting Audit Quality: The Moderating Effect of Dysfunctional Behavior," Universal Journal of Accounting and Finance, Vol. 10, No. 1, pp. 358 366, 2022. DOI: 10.13189/ujaf.2022.100136.

(b): Aldi Rivaldi, Khoirul Aswar, Taufeni Taufik, Andreas, Eka Hariyani (2022). Factors Affecting Audit Quality: The Moderating Effect of Dysfunctional Behavior. Universal Journal of Accounting and Finance, 10(1), 358 - 366. DOI: 10.13189/ujaf.2022.100136.

Copyright $\odot 2022$ by authors, all rights reserved. Authors agree that this article remains permanently open access under the terms of the Creative Commons Attribution License 4.0 International License

\begin{abstract}
This study aims to examine the Machiavellian characteristic, independence, time budget pressure, and dysfunctional behavior as moderating variables on audit quality. Main Auditor of State Finance (AKN) of the Supreme Audit Institution of the Republic of Indonesia (BPK RI) was used as samples in this study. The purposive sampling method was used to select 52 examining auditors from AKN who completed a questionnaire. The hypothesis in this study was investigated using the SmartPLS 3.0 and the Structural Equation Modelling (SEM). This study will provide information to supreme audit institution in order to maintain and improve the quality of BPK RI. The result of this study shows that independence and time budget pressure had a significant effect on audit quality, while machiavellian characteristics had no significant effect on audit quality. The influence of machiavellian characteristics, independence, and time budget pressure on audit quality is not moderated by dysfunctional behavior. This research is expected to be useful for the leadership of the supreme audit agency in reviewing policies related to improving audit quality and paying attention to the condition of the auditor in carrying out audit assignments so that the reliability of the BPK LHP is maintained.
\end{abstract}

Keywords Audit Quality, Machiavellian Characteristic, Independence, Time Budget Pressure, Dysfunctional Behavior

\section{Introduction}

An auditor, in carrying out his profession, is not only required to have competence but also must be able to execute audit standards and the code of ethics of his profession. Audit standards and professional code of ethics for auditors must be carried out in order to stabilize the audit quality. The actions he takes are intended for the public interest, so all the basic principles and applicable professional ethics must be obeyed and applied properly [1]. With regard to public sector audits, the Government Accountability Office (GAO), which is the Supreme Audit Institution (BPK) of the United States of America explained that as long as the audit task is carried out, audit quality is an adherence to professional standards and contractual ties [2].

According to DeAngelo [3] the auditor's ability to detect and state indications related to violations committed by clients through the accounting system can be measured using audit quality as an assessment of the possibility of whether or not there are indications of violations. The quality of the audit produced by an auditor in carrying out his work greatly affects the level of trust held by the public as users of financial statements on the accounting profession. Indirectly, this illustrates that the responsibility of the auditor is not only focused on the community but also on the existence of the profession.

When conducting an audit, the BPK auditor must be motivated by the level of compliance with audit policies and procedures that are in accordance with Law No. 15 of 
2006 concerning the Financial Audit Board as regulated in BPK Regulation No. 1 of 2017 concerning Financial Audit Standards Country. In addition, as stipulated in BPK Regulation Number 4 of 2018 concerning the code of ethics of BPK, to enforce the code of ethics, which is the basic value for BPK and includes, independence, integrity, and professionalism.

In Indonesia, it was found based on the Semester Examination Results Summary (IHPS) I of 2020 which has been published, containing a summary of examination results with details as follows: from a total of 680 Audit Result Reports (LHP) consisting of 634 or $93 \%$ Financial LHP, 7 or $1 \%$ Performance LHP, and 39 or $6 \%$ LHP with a Specific Purpose. BPK also stated that the total findings obtained were around 7,868 findings containing 13,567 problems amounting to Rp8.97 trillion, consisting of 6,713 or $50 \%$ problems with weaknesses in the internal control system (SPI) and 6,702 or $49 \%$ other problems related to non-compliance with the provisions of laws and regulations. amounting to Rp8.28 trillion, and 152 or $1 \%$ problems of ineffectiveness, inefficiency, and ineffectiveness of Rp. 692.05 billion. This means, there are still many auditing auditors at BPK who still carry out their assignments that are not in accordance with the applicable professional code of ethics. This is evidenced from the results of the Regional Government Financial Reports (LKPD) in the BPK IHPS where many regions, both provinces and districts, have received Unqualified Opinions (WTP) by the BPK, even though regional heads in those regions have committed criminal acts of corruption such as Lombok Province, Talaud Regency, and parts of it.

This research adds to the body of knowledge about machiavellian characteristics, independence, time budget pressure, moderating variables, such as dysfunctional behavior, and audit quality. Noor [4] uses machiavellian characteristic but does not consider independence, time budget pressure, and dysfunctional behavior. Then Aswar et al. [5] used independence and time budget pressure but did not consider Machiavellian characteristics. This study adds a machiavellian characteristic according to the recommendations of [6] and [5] and there is a moderating variable, namely dysfunctional behavior. Furthermore, the purpose of this study is to examine the effect of Machiavellian characteristic, independence, time budget pressure and audit quality. Also, examines the moderating effect of dysfunctional behavior on audit quality.

\section{Literature Review and hypothesis Development}

\subsection{Theoretical Perspective}

Attribution theory explains the process by which individuals perform an analysis of a person's behavioral motives. Luthans [7] argues that the attribution theory of things that have an impact on a person's behavior can be caused by the individual's internal factors (character and nature) or pressure from external factors. Attribution is divided into 2, namely dispositional attributions that focus on individual attitudes that exist within a person. Individual behavior in question such as personality, self-perception, motivation, and ability. Meanwhile, situational attributions focus on the surrounding environment that is able to influence one's attitudes such as social values and community views. Internal or external variables can influence an individual's decision to take a specific activity. The attribution theory is critical in understanding how the auditor behaves during the audit process in order to produce an audit report. The audit quality can be guaranteed if the auditor responds wisely to any information that is used in audit methods. However, if the auditor tends to lower the audit quality during the implementation of the audit program, this is referred to as dysfunctional conduct.

The inverted-U theory states that performance will increase if the level of pressure is still in accordance with the ability, when the level of performance increases too high or too much pressure, the actual performance will decrease. Therefore, if the pressure level is low, the execution of the given task will be done better, more intensely, and faster. According to Broadhurst [8], when a person's driving factor is either too low or too high, their performance suffers as a result. If, on the other hand, the supplied driving power has reached its maximum level, the subsequent achievement or performance will also reach its maximum level. Zakaria et al. [9] states that audit quality becomes low if the auditor feels pressured in a situation that forces him to complete the audit process in a short time.

\subsection{Audit Quality}

In previous studies, many studies have discussed Machiavellian characteristics in influencing the level of audit quality. Focusing on the machiavellian characteristic, [4] tested the machiavellian characteristic on audit quality which resulted if the machiavellian characteristic had an insignificant effect on audit quality. The results show that Machiavellian characteristics do not have a relationship with the quality of the audit produced by an auditor.

In a separate study, the impact of independence on audit quality was investigated by [5], who discovered that independence had no effect on audit quality. The findings show that an auditor's independence attitude has no bearing on the amount of audit quality that the auditor examiner would generate. Furthermore, Ningsih and Yaniartha [6] looked at the impact of time budget pressure on audit quality, finding that the more under time budget pressure an auditor, the lower the audit quality produced, and vice versa. According to the data, time budget pressure has a significant negative impact on audit quality. Fatimah [10] investigated the link between dysfunctional behavior and 
audit quality as well. The study's findings show that if an auditor engages in dysfunctional conduct while performing his job, the quality of the audit performed would suffer. On the other side, if you reduce the usage of dysfunctional conduct, the audit quality will naturally improve.

\section{Hypotheses Development}

The following are the hypotheses in this study, which are based on factors that are thought to have an impact on audit quality and dysfunctional behavior as a moderating factor:

\subsection{Machiavellian Characteristics}

Machiavellian characteristics are low empathy for others and tend to be anti-social. The individual has a selfish and manipulative nature, and has loyalties and ideologies that can endanger themselves and the company in achieving their goals. Machiavelianism was coined by Niccolo Machiavelli, a political philosopher in Italy (1469-1527). According to Srini [11] which found audit quality was significantly influenced by Machiavellian characteristics. This can be interpreted that if a public accountant has a high Machiavellian level, the impact will result in the audit report being produced to be of low quality because it has the potential to be cheated or manipulated by the public accountant concerned to benefit himself.

Machiavellian personality tends to do things that will benefit him. Machiavellian characteristics include a negative personality that everyone has and ignores morality and integrity at work. According to the attribution theory, machiavellian characteristics include the type of personality that is a factor in the auditor. Attribution theory defines individual behavior can occur because of encouragement both in terms of internal and external. For auditors, Machiavellian characteristics are internal factors that can have an impact on the level of audit quality. Srini [11] and Saryati and Dewi [12] resulted in machiavellian characteristics influenced by audit quality.

H1: Machiavellian characteristics have a significant effect on audit quality.

\subsection{Independency}

The quality of audits produced by an auditor can also be affected by independence. According to Mautz and Sharaf [13], an independent auditor is someone who is capable of uncovering all frauds, errors, and frauds instigated by management, and reporting audit findings in the audited report when objective aspects are taken into account to create audit findings. and the ability to express oneself is contingent on a self-reliant mindset. Al-Khaddash et al. [14], Halim et al. [15], Sarwoko and Agoes [16], Alzeban and Gwilliam [17], and Tepalagul and Lin [18] all found that independence increased audit quality positively and considerably. It can be interpreted that audit quality will decrease if there is independence disorder, this will certainly cause the auditor to be not objective in providing opinions or conclusions about the conditions under consideration and may have an impact on audit quality decline.

Auditor independence is one of the elements or internal attributions for increasing audit quality. This is due to the auditor's ability, if they are independent to report fraud discovered in the client's accounting system [3]. The auditor's independence determines whether or not he or she will not report a substantial misstatement finding. If auditors are unable to preserve their independence, audit quality will undoubtedly suffer [19]. Results from previous study found that there is a significant relationship between independence and audit quality [14]; [18].

H2: Independence has a significant effect on audit quality.

\subsection{Time Budget Pressure}

Other factor that affects on audit quality is time budget pressure. According to Halim et al. [15], time budget pressure in the audit process will damage auditor expertise by limiting scope, relying on lower quality evidence, missing some audit processes, and overlooking audit risk. According to Ningsih and Yaniartha [6], Fitria [20], and Al-Qatamin [21], time budget pressure has a negative impact on audit quality. This demonstrates that when auditors are under a lot of time and money strain, their quality can suffer. In such circumstances, the auditor will be forced to choose between dysfunctional and normal behavior. It is different from results of [5] that audit quality is not significantly affected by time budget pressure.

The relationship between audit quality and time budget pressure is defined using the inverted-U theory. This theory states that when a person's push factor is too high, their performance suffers as a result. If the supplied driving force, on the other hand, has achieved its maximum level, The resulting achievement or performance will also be at its peak [8]. According to Al-Qatamin [21] and Ningsih and Yuniartha [6], time budget constraints have a significant negative impact on audit quality.

H3: Time budget pressure has a significant effect on audit quality.

\subsection{Dysfunctional Behavior as a Moderationg}

The presence of dysfunctional behavior is thought to be a moderating factor in audit quality. According to Kelley and Margheim [22], dysfunctional behavior has an impact on audit quality. This is due to the fact that dysfunctional behavior deviates from auditing criteria. This behavior is indicative of reckless behavior when it comes to finishing responsibilities. Audit conduct that is dysfunctional, such as abruptly terminating audit procedures, modifying audit phases, and reducing processing time. This result differs from that of [23], who found that dysfunctional conduct 
has no impact on audit quality.

When it comes to carrying out duties, an auditor with a high level of Machiavellian qualities has the potential to be dysfunctional. According to Winanda and Wirasedana [24], if an auditor has a high Machiavellian propensity, he will strive to profit from the situation and will break restrictions, resulting in dysfunctional behavior. Of course, this behavior will have an impact on the quality of the audits that an auditor produces while performing audit assignments.

Dysfunctional behavior of auditors is related to attribution theory. Dysfunctional behavior can occur because the auditor accepts pressure that is outside his control, so that with this pressure, the auditor will perform dysfunctional behavior in his assignment. According to Yuen et al. [25], any danger to audit quality will have an impact on independence. If the auditor disregards independence, there is a risk that anomalies in the financial statements will go unreported, lowering audit quality, and the auditor will be obliged to engage in dysfunctional conduct in order to complete his work.

Arnold et al. [26] explain that a narrow time budget in an audit assignment has the potential to reduce auditor competence. Auditors tend to analyze in a limited scope, rely on less reliable evidence, and omit some audit procedures. If dysfunctional behavior is carried out to a minimum by the auditor, of course, audit quality will increase in reliability even in conditions of high time budget pressure. This assertion is in line with [27], who discovered that auditors who are under a lot of time budget pressure are more likely to act dysfunctional, and vice versa.

H4: Machiavellian characteristic moderated by dysfunctional behavior has a significant effect on audit quality.

H5: Independence moderated by dysfunctional behavior has a significant effect on audit quality.

H6: Time budget pressure moderated by dysfunctional behavior has a significant effect on audit quality.

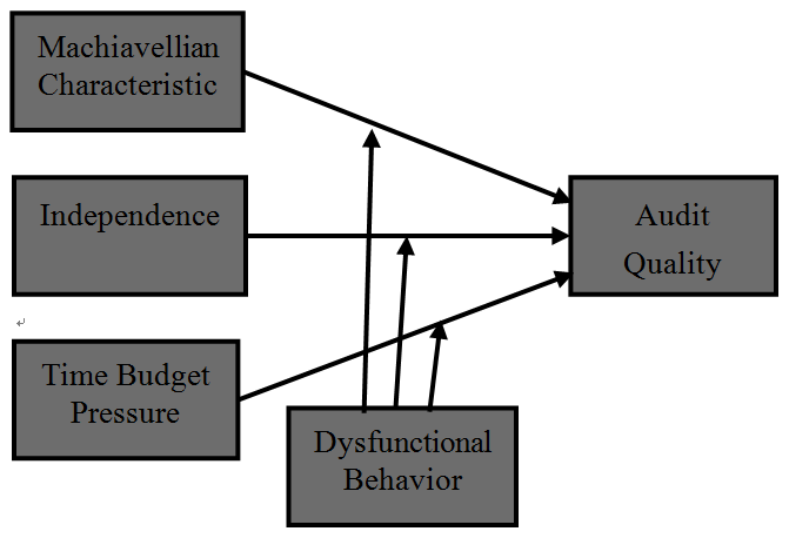

Figure 1. Research Framework

\section{Methodology}

The population of this study is the BPK of the Republic of Indonesia's Main Auditorate of State Finance (AKN) V and VI (BPK RI). All auditors who served in AKN V and VI of the BPK RI were included in this study's sample. A total of 52 auditors from AKN V and VI were used in this study. Purposive sampling technique was utilized to collect samples from the complete population of this study based on the criteria set, with the criterion being auditors who have served as examiners of regional financial statements for at least two years.

Furthermore, data collection for this research was carried out through the distribution of questionnaires distributed through the Bureau of Public Relations and International Cooperation. The data collected are the result of a questionnaire obtained through the WhatsApp application and google form in coordination with the Bureau of Public Relations and International Cooperation which distributes it to the Administration in the AKN V and VI units of BPK RI. Each variable in this study has its own measurement, which was adopted from previous research. Variable measurement methods are shown in Table 1.

Table 1. Variable Measurement

\begin{tabular}{|c|c|c|c|c|}
\hline Variable & Indicator & Scale & Question & Source \\
\hline Audit Quality & $\begin{array}{l}\text { The ability of the auditor to detect } \\
\text { misstatements; credibility of financial } \\
\text { statement information; conformity with } \\
\text { applicable auditing standards. }\end{array}$ & Likert & 12 & Aswar et al. [5] \\
\hline Machiavellian Characteristic & $\begin{array}{l}\text { Affection; low ideological commitment; } \\
\text { ego; manipulative; aggressive. }\end{array}$ & Likert & 15 & Noor [4] \\
\hline Independence & $\begin{array}{c}\text { Independence of program planning; } \\
\text { investigative independence; reporting } \\
\text { independence. }\end{array}$ & Likert & 10 & Aswar et al. [5] \\
\hline Time Budget Pressure & $\begin{array}{l}\text { Acceptance of client explanations; } \\
\text { reduction/termination of audit } \\
\text { procedures; execution of assignments } \\
\text { when the time budget is tight. }\end{array}$ & Likert & 8 & Risanti et al. [39] \\
\hline Dysfunctional Behavior & $\begin{array}{l}\text { Premature sign-off; underreporting of } \\
\text { time; change audit procedures. }\end{array}$ & Likert & 12 & $\begin{array}{l}\text { Donnely et al. } \\
{[28]}\end{array}$ \\
\hline
\end{tabular}




\section{Result}

\subsection{Data Description}

Samples were selected using purposive sampling technique. Table 2 shows a description of the data of this study.

Table 2. Description of Research Data

\begin{tabular}{|c|c|c|c|}
\hline Characteristics & Information & Frequency & Percentage \\
\hline \multirow{2}{*}{ Gender } & Man & 26 & $50 \%$ \\
\hline & Woman & 26 & $50 \%$ \\
\hline \multirow{4}{*}{ Age } & 21 - 30 years & 5 & $9,6 \%$ \\
\hline & 31 - 40 years & 24 & $46,2 \%$ \\
\hline & 41 - 50 years & 14 & $26,9 \%$ \\
\hline & $\begin{array}{c}\text { More than } 50 \\
\text { years }\end{array}$ & 9 & $17,3 \%$ \\
\hline \multirow{2}{*}{$\mathrm{AKN}$} & AKN V & 43 & $82,7 \%$ \\
\hline & AKN VI & 9 & $17,3 \%$ \\
\hline \multirow{4}{*}{ Experience } & $2-5$ years & 3 & $5,8 \%$ \\
\hline & $6-10$ years & 11 & $21,2 \%$ \\
\hline & $11-15$ years & 22 & $42,3 \%$ \\
\hline & $\begin{array}{c}\text { More than } 15 \\
\text { years }\end{array}$ & 16 & $30,8 \%$ \\
\hline \multirow{4}{*}{ Education } & Diploma & 0 & $0 \%$ \\
\hline & $\begin{array}{c}\text { Bachelor } \\
\text { degree }\end{array}$ & 29 & $55,8 \%$ \\
\hline & Postgraduate & 23 & $44,2 \%$ \\
\hline & Doctorate & 0 & $0 \%$ \\
\hline
\end{tabular}

\subsection{Descriptive Statistics}

After filtering the population data such as table 2, then conducted some data analysis using the Structural Equation Model (SEM) with the SmartPLS version 3.0 application. Descriptive statistics of the data are in table 3.

The mean for audit quality is 4.12 , with a standard deviation of 0.548 , according to the descriptive statistics in table 3. The mean of the Machiavellian trait is 2.33 , and the standard deviation is 0.681 . Furthermore, the independence mean is 3.48 with a standard deviation of 0.464 . Meanwhile, with a standard deviation of 0.737 , the average time budget pressure is 2.36. Finally, the mean for dysfunctional conduct was calculated to be 2.67 with a standard deviation of 0.323 .

Table 3. Data Descriptive Statistics

\begin{tabular}{cccc}
\hline Variable & $\begin{array}{c}\text { Total } \\
\text { Item } \\
\text { Statement }\end{array}$ & Mean & $\begin{array}{c}\text { Standard } \\
\text { Deviation }\end{array}$ \\
\hline $\begin{array}{c}\text { Audit Quality } \\
\text { Machiavellian }\end{array}$ & 12 & 4,12 & 0,548 \\
Characteristics & 15 & 2,33 & 0,681 \\
$\begin{array}{c}\text { Independence } \\
\text { Time Budget Pressure }\end{array}$ & 10 & 3,48 & 0,464 \\
Dysfunctional Behavior & 12 & 2,36 & 0,737 \\
\hline
\end{tabular}

\subsection{Hypothesis Testing and Discussion}

This study uses analysis data with smartPLS version 3.0. Before to analyze this data starts with validity and reliability test.

Table 4. Convergent Reliability Test and Validity Test

\begin{tabular}{cccc}
\hline Variable & $\begin{array}{c}\text { Average Varian } \\
\text { Extracted }(\text { AVE) }\end{array}$ & $\begin{array}{c}\text { Composite } \\
\text { Reliability }\end{array}$ & $\begin{array}{c}\text { Cronbach's } \\
\text { Alpha }\end{array}$ \\
\hline DBH & 0,730 & 0,931 & 0,912 \\
IND & 0,636 & 0,896 & 0,854 \\
KUA & 0,539 & 0,854 & 0,787 \\
MCH & 0,527 & 0,886 & 0,852 \\
TBP & 0,620 & 0,907 & 0,878 \\
\hline
\end{tabular}

In table 4 above, it is explained that for the reliability test consisting of the results of the composite reliability test and Cronbach's alpha, each described by [29] for standard composite reliability the minimum value is 0.7 while for Cronbach's alpha the minimum value is 0.6. From the results of the tests that have been carried out, it is found that for all the variables used in this study have met the criteria for good reliability of each construct if we look at the reliability test. This happens because the value generated from the test is already above 0.7 and 0.6. Meanwhile, for the convergent validity test carried out, it can be seen from the results of the average variance extracted (AVE) which is explained by [30] the standard or minimum value is 0.50 . The results of the tests carried out on the variables used in this study were all displayed values above 0.50 . So, it can be concluded that all the variables used in this study are considered valid.

Table 5. Discriminant Validity Test

\begin{tabular}{cccccc}
\hline & $\begin{array}{c}\text { Dysfunctional } \\
\text { Behavior (DBH) }\end{array}$ & $\begin{array}{c}\text { Independence } \\
\text { (IND) }\end{array}$ & $\begin{array}{c}\text { Audit Quality } \\
\text { (KUA) }\end{array}$ & $\begin{array}{c}\text { Mach. Charac. } \\
\text { (MCH) }\end{array}$ & $\begin{array}{c}\text { Time Budget } \\
\text { Pressure (TBP) }\end{array}$ \\
\hline DBH & 0,855 & & & & \\
IND & $-0,035$ & 0,797 & & & \\
KUA & $-0,24$ & 0,435 & 0,734 & 0,726 & 0,787 \\
MCH & 0,32 & $-0,076$ & $-0,456$ & 0,623 & \\
TBP & 0,349 & $-0,336$ & $-0,668$ & & \\
\hline
\end{tabular}


In the discriminant validity test, this study uses the Farnell-lacker as a test tool, which in this test the standard or minimum value is 0.6 [29]. Dysfunctional behavior (DBH) has a value of 0.855 , independence (IND) has a value of 0.797 , audit quality (KUA) has a value of 0.734 , TBP is 0.787 , and Machiavellian characteristic $(\mathrm{MCH})$ is 0.726 . As a result, it is possible to declare all constructs on each variable to be legitimate.

Table 6. Testing PLS Path Algorithm and Bootstrapping

\begin{tabular}{cccc}
\hline Variable & $\begin{array}{c}\text { Path } \\
\text { Coefficient } \\
\text { (Original } \\
\text { Sample })\end{array}$ & $\begin{array}{c}\boldsymbol{T} \text { - } \\
\text { Statistics }\end{array}$ & $\boldsymbol{P}$ - Values \\
\hline MCH -> KUA & $-0,123$ & 0,771 & 0,441 \\
IND -> KUA & 0,258 & 2,466 & 0,014 \\
TBP -> KUA & $-0,505$ & 3,330 & 0,001 \\
MCH*DBH -> KUA & 0,026 & 0,168 & 0,867 \\
IND*DBH -> KUA & 0,013 & 0,109 & 0,913 \\
TBP*DBH -> KUA & 0,002 & 0,009 & 0,993 \\
\hline
\end{tabular}

The test results in Table 6 show that the Machiavellian characteristic path coefficient on audit quality is -0.123 and negative. The findings of testing the Machiavellian Characteristic (MCH) on audit quality (KUA) showed a $\mathrm{t}$-count t-table of 0.7712 .01174 and a significant value of $0.441>0.050$ based on the data processing results. These results indicate that $\mathrm{H} 1$ is rejected because Machiavellian characteristics do not have a significant effect on audit quality. This illustrates that all audit auditors in this study have a low level of Machiavellian characteristics in themselves, so that auditors do not carry out activities that have the potential to reduce audit quality such as manipulative, persuasive, and other fraudulent actions in conducting audits. The findings of this investigation do not support Heider's attribution hypothesis [31]. This theory explains how the audit quality produced by the auditors is influenced by several internal auditor factors, such as machiavellian characteristics, because these results show that the BPK RI auditors, especially in AKN V and VI, in carrying out their duties comply with applicable accounting standards and carry out assignments in accordance with the professional code of ethics. This result is also in line with the findings of other earlier studies, like [12] and [4], which show that Machiavellian qualities have a insignificant impact on audit quality. However, this result contradicts of [8] which states that Machiavellian characteristics have a significant effect on audit quality.

The independent path coefficient value on audit quality is 0.258 and is positive. This proves that independence has a positive effect on audit quality. Based on the results of data processing, the $\mathrm{t}$-count $>\mathrm{t}$-table value of $2.466>$ 2.01174 and a significance value of 0.0140 .050 are the findings of the independence test (IND) on audit quality (KUA). These results indicate that independence has a significant effect on audit quality, so $\mathrm{H} 2$ is accepted. This result means that each indicator on independence almost entirely contributes maximally to audit quality. This is due to the fact that the study's sample is dominated by auditors with more than ten years of experience, as many as 38 people $(73 \%)$ which in general will certainly strongly instill an attitude of independence, because these auditors really understand the meaning of independence which is one of the BPK RI's professional codes of ethics. As a result, the auditor can carry out audit assignments without interference from supervisors or clients. The findings of this study back up the attribution hypothesis, which explains the link between audit quality and independence. One of the cause aspects (internal attribution) in establishing a quality audit is independence. This result is also in line with the findings of [14], [18], [15], and [16], who all claim that audit quality is affected by independence.

The time budget pressure route coefficient for audit quality is -0.505 , which is negative. This indicates that audit quality suffers when time resources are limited. Based on the data processing results, the time budget pressure (TBP) test on audit quality (KUA) reveals a $\mathrm{t}$-count > t-table of $3.330>2.01174$ and a significance value of 0.0010 .050 . These findings support $\mathrm{H} 3$, indicating that time budget pressure has a major impact on audit quality. The findings of this study suggest that because the auditors in this study are under pressure to finish audit reports in a short amount of time, they are more likely to compromise audit quality, which will have an impact on the audit report produced. This study's findings back this up the inverted- $U$ theory, which argues that a person's performance degrades when their push/pressure factor is too low or too high. If, on the other hand, the given push/pressure factor has reached its optimal level, the subsequent accomplishment or performance will also be at its peak [8]. When an auditor is under pressure to finish the audit in the allotted time, they are more prone to adopt activities that compromise audit quality. These findings are consistent with recent research from [21], [20], and [6], all of which suggest that audit quality suffers as a result of time budget pressure.

For dysfunctional behavior modifying the influence of Machiavellian feature on audit quality, the positive path coefficient value is 0.026 . According to the data processing results, the influence of the association between Machiavellian characteristic $(\mathrm{MCH})$ and audit quality (KUA) was moderated by dysfunctional behavior (DBH) test results, with a tcount table of 0.1682 .01174 and a significant value of $0.867>0.050$. As a result of these findings, $\mathrm{H} 4$ is rejected since the effect of the relationship between Machiavellian characteristic and audit quality cannot be mitigated by dysfunctional behavior. This means that if the auditor exhibits dysfunctional behavior, it does not imply that the auditor is machiavellian in his performance of his duties, and the quality of the subsequent audit is unaffected.

Furthermore, it can be seen from the table of descriptive 
data that practically all auditors lack Machiavellian qualities, making it unlikely that auditors will engage in dysfunctional audit behavior. Low audit quality can result from this dysfunctional conduct. The findings of this study agree with those of [32] and [33], who show that machiavellian characteristics are distinct from dysfunctional conduct, implying that government auditors maintain a high level of morale. This result, however, contradicts the findings of [34], [35], and [24], who found that if an auditor has a strong Machiavellian feature, he will try to use the circumstance for personal gain and have a tendency to ignore rules, a person is more likely to engage in dysfunctional behavior.

The positive path coefficient of dysfunctional behavior mitigating the effect of independence on audit quality is 0.013. The influence of the association between independence (IND) and audit quality (KUA) was moderated by dysfunctional behavior (DBH) test results, which showed a t-count t-table of 0.1092 .01174 and a significance value of $0.913>0.050$. As a result of these findings, $\mathrm{H} 5$ is rejected because dysfunctional behavior has no effect on the relationship between independence and audit quality. Most of the auditors in this study have independence in line with the BPK RI professional code of ethics, which requires them to report any discovery of mistakes or irregularities in the object under examination so that the quality of the audit generated is not harmed. Furthermore, it can be seen from the table of descriptive statistics that practically all auditors have independence in themselves, indicating that auditors are unlikely to conduct dysfunctional behavior audits. Because of this dysfunctional conduct, audit quality can suffer. The findings of this study support [36] theory that the greater the auditor's independence, the less likely they are to engage in dysfunctional audit behavior. The results of the data processing reveal that auditor independence has no bearing on dysfunctional audit behavior. This study's findings are also consistent with [23] findings, which show that dysfunctional conduct has no effect on the association between parameters that determine audit quality, such as task complexity, experience, and independence. This result, however, contradicts Tepalagul and Lin [18] and Yuen et al. [25], who claim that any threat to audit quality will harm independence. If the auditor ignores independence, there is a tendency not to report financial statement irregularities, which will surely degrade audit quality, and the auditor will be obliged to engage in dysfunctional conduct to complete his work.

The value of dysfunctional behavior influencing the effect of time budget pressure on audit quality is 0.002 . The results of dysfunctional behavior $(\mathrm{DBH})$ testing moderated the effect of the relationship between time budget pressure and audit quality, with a t-count t-table value of 0.009 2.01174 and a significant value of $0.993>0.050$, based on the data processing results. As a result of these findings, H6 is rejected because dysfunctional behavior cannot regulate the relationship between time budget pressure and audit quality. This implies that auditors do not necessarily perform strangely when they are under a lot of pressure owing to a limited audit time budget. Time budget pressure is caused by the needs of professional employment, whereas dysfunctional behavior is motivated by each auditor's personal interests. The findings of this study support those of [37], who found no link between time budget pressure and the occurrence of dysfunctional behavior. However, these findings contradict the findings of [39], [25], and [27], who claim that auditors under high time budget pressure are more likely to engage in dysfunctional behavior, vice versa. Furthermore, this finding contradicts [20], who claims that dysfunctional behavior can mitigate the impact of time budget pressure on audit quality.

\section{Conclusion and Recommendations}

This study aims to examine the machiavellian characteristic, independence, time budget pressure and dysfunctional behavior as moderating on audit quality. The results of this study found that independence and time budget pressure had a significant effect on audit quality. Meanwhile, Machiavellian characteristic has no significant effect on audit quality. Dysfunctional behavior cannot moderate the effect of Machiavellian characteristic, independence, time budget pressure on audit quality. The findings of this study are expected to be an illustration so that the independence attitude is more instilled into each auditor in accordance with the professional code of ethics which is the standard in carrying out audit assignments. Following that, it is envisaged that all BPK auditors, particularly AKN V and VI auditors, will get further training and practical experience as a result of the audit process, enabling auditors to get unique perspectives, allowing them to better detect material misstatements in financial statements despite being under time constraints. Furthermore, auditors are expected to have high morale or stronger motivation in carrying out audit assignments properly.

The limitation obtained in this study is the number of respondents in this study as many as 52 respondents, while the total sample given by the questionnaire was 90 respondents. There were $38(42.2 \%)$ respondents who did not fill out the questionnaire. This happens because the samples used in this study, namely AKN V and VI are currently carrying out annual LKPD reporting to every province throughout Indonesia, so it is quite difficult to get data that are in accordance with what was planned because of the current condition of each auditor used in the sample. they are both busy. Further research is suggested to add several other variables that may affect the level of audit quality such as task complexity, auditor professionalism, locus of control, auditor integrity and so on. Then, hopefully, future research will broaden the scope of the study and increase the number of respondents who serve as 
study samples, allowing for more accurate and valid conclusions that accurately depict the actual situation.

\section{REFERENCES}

[1] IAPI. (2016). Draf panduan indikator kualitas audit pada kantor akuntan publik. Jakarta. From: http://iapi.or.id/uplo ads/article/exposure-draft-panduanindikatorkualitas-audit5804a2d00298b.pdf (accessed: April 12, 2021).

[2] Samelson, D., Lowensohn, S., Johnson, L. E. 'The determinants of perceived audit quality and auditee satisfaction in local government' Journal of Public Budgeting, Accounting \& Financial Management, vol.18, no.2, pp. 139-166, 2006.

https://doi.org/10.1108/JPBAFM-18-02-2006-B001

[3] DeAngelo, L.E. "Auditor size and audit quality", Journal of Accounting \& Economics, vol.3, no.3, pp. 183-199, 1981. https://doi.org/10.1016/0165-4101(81)90002-1

[4] Noor, M. A. M. "Pengaruh kecerdasan emosional, continuing professional development, dan sifat machiavellian terhadap kualitas audit," Skripsi. Universitas Negeri Semarang. 2017.http://lib.unnes.ac.id/id/eprint/299 38

[5] Aswar, K., Akbar, F. G., Wiguna, M., \& Hariyani, E. "Determinants of audit quality: Role of time budget pressure", Problems and Perspectives in Management, vol.19, no.2, pp.308-319, 2021.

http://dx.doi.org/10.21511/ppm.19(2).2021.25

[6] Ningsih. A. P. R. C., \& Yaniartha S., P. D. "Pengaruh kompetensi, independensi, dan time budget pressure terhadap kualitas audit", E-Jurnal Akuntansi, vol.4, no.1, pp. 92-109, 2013.

https://ojs.unud.ac.id/index.php/Akuntansi/article/view/58 96

[7] Luthans F, Youssef-Morgan CM, Avolio B. "Psychological Capital and Beyond. New York: Oxford Univ. Press. 2017. https://digitalcommons.unl.edu/managementfacpub/165?ut $\mathrm{m} \_$source $=$digitalcommons.unl.edu $\% 2 \mathrm{Fmanagementfacpu}$ b\%2F165\&utm_medium=PDF\&utm_campaign=PDFCove rPages

[8] Broadhurst, P. L. "The interaction of task difficulty and motivation: The Yerkes Dodson law revived", Acta Psychologica, vol.16, pp. 321-338, 1959. https://doi.org/10.1016/0001-6918(59)90105-2

[9] Zakaria, N. B., Yahya, N., \& Salleh, K. "Dysfunctional behavior among auditors: The application of occupational theory", Journal of Basic and Applied Scientific Research, vol.3, no.9, pp. 495-503, 2013.

https://www.textroad.com/pdf/JBASR/J.\%20Basic.\%20Ap pl.\%20Sci.\%20Res.,\%203(9)495- 503,\%202013.pdf.

[10] Fatimah, A. "Karakteristik personal auditor sebagai anteseden perilaku disfungsional auditor dan pengaruhnya terhadap kualitas hasil audit", Jurnal Manajemen dan Akuntansi, Vol.1, no.1, 2012. Retrieved from https://media.neliti.com/media/publications/111808-ID-kar akteristik-personal-auditor-sebagai-a.pdf

[11] Srini. S. "Uji multi stage pengaruh karakteristik personal auditor terhadap kualitas audit melalui perilaku dysfungsional audit dengan pendekatan keputusan berbasis etis (studi kasus pada kap di sumatera bagian tengah)," JOM Fekon, vol.2, no.2, 2015. https://media.neliti.com/me dia/publications/34031-ID-uji-multi-stage-pengaruh-karakt eristik-personal-auditor-terhadap-kualitas-audit.pdf

[12] Saryati, S., \& Dewi, R. R. "Pengaruh sifat machiavellian dan kompetensi terhadap kualitas audit (studi empiris pada auditor Badan Pemeriksa Keuangan)", Seminar Nasional UNIRBA Surakarta, vol.2, no.1, pp. 19-149, 2016.

[13] Mautz, R. K., \& Sharaf, H. A. "The Philosophy of Auditing, American Accounting Association", Monograph No. 6. Sarasota, FL: American Accounting Association, 1961. https://www.worldcat.org/title/philosophy-of-auditing/oclc /355634

[14] Al-Khaddash, H., Al Nawas, R., \& Ramadan, A. "Factors affecting the quality of auditing: The case of Jordanian Commercial Banks", International Journal of Business and Social Science. Vol.4, no. 11, pp. 206-222, 2013. Retrieved from https://www.ijbssnet.com/journals/Vol_4_No_11_Se ptember_2013/20.pdf

[15] Halim, A., Sutrisno, T., Rosidi, \& Achsin, M. "Effect of competence and auditor independence on audit quality with audit time budget and professional commitment as a moderation variable", International Journal of Business and Management Invention, vol.3, no.6, pp. 64-74, 2014. http://ijbmi.org/papers/Vol(3)6/Version-1/I0361064074.pd f.

[16] Sarwoko, I., \& Agoes, S. "An empirical analysis of auditor's industry specialization, auditor's independence and audit procedures on audit quality: Evidence from Indonesia", Procedia - Social and Behavioral Sciences, vol.164, pp. 271-281, 2014.https://doi.org/10.1016/j.sbspr o.2014.11.077

[17] Alzeban, A., \& Gwilliam, D. "Factors affecting the internal audit effectiveness: A survey of the Saudi public sector", Journal of International Accounting, Auditing and Taxation, vol.23, no.2, pp. 74-86, 2014. https://doi.org/10.1016/j.int accaudtax.2014.06.001

[18] Tepalagul, N., \& Lin, L. "Auditor independence and audit quality: A literature review", Journal of Accounting, Auditing \& Finance, vol.30, no.1, pp.101-121, 2014. https://doi.org/10.1177/0148558X14544505

[19] Deis, D., \& Giroux, G. "Determinants of audit quality in the public sector", The Accounting Review, vol.67, no.3, pp. 462-479, 1992. https://www.jstor.org/stable/247972

[20] Fitria, M. "Pengaruh time budget pressure, due professional care dan etika auditor terhadap kualitas audit dengan perilaku disfungsional auditor sebagai moderator (study empiris pada kantor akuntan publik di Pekanbaru dan Medan)", JOM Fekon, vol.3, no.1, 2016.https://www.neliti .com/publications/124949/pengaruh-time-budget-pressuredue-professional-care-dan-etika-auditor-terhadap-k

[21] Al-Qatamin, K. I. "The impact of time pressure on the audit quality: A case study in Jordan”, IOSR Journal of Business and Management. vol.22, no.1, pp.08-16, 2020. https://doi.org/10.9790/487X- 2201050816

[22] Kelley, T., \& Margheim, L. "The impact of time budget pressure, personality, and leadership variables on dysfunctional auditor behavior", Auditing-A Journal of 
Practice \& Theory, vol.9, no.2, pp. 21-42, 1990. https://www.researchgate.net/publication/284885847_The _impact_of_time_budget_pressure_personality_and_leader ship_variables_on_dysfunctional_auditor_behavior

[23] Suprapto, F. M., \& Nugroho, W. C. "Pengaruh kompleksitas tugas terhadap kualitas audit dengan disfungsional auditor sebagai variabel moderasi", Akuntabilitas: Jurnal Ilmu Akuntansi, vol.13, no.2, pp.151-164, 2020.

https://core.ac.uk/download/pdf/348263779.pdf

[24] Winanda, I. K. H., \& Wirasedana, I. W. P. "Pengaruh tekanan anggaran waktu, sifat machiavellian dan kompleksitas tugas terhadap perilaku audit disfungsional", E-Jurnal Akuntansi Universitas Udayana, vol.18, no.1, pp.500-528, 2017.

https://ojs.unud.ac.id/index.php/Akuntansi/article/view/24 432

[25] Yuen, P., Desmond, C., Law, C., \& JieQi, G. "Dysfunctional auditing behaviour: empirical evidence on auditors behaviour in Macau",International Journal of Accounting and Information Management, vol.4, no.5. pp.1-20, 2013.

https://doi.org/10.1108/IJAIM-12-2012-0075

[26] Arnold, V., Sutton, S. G., Hayne, S. C., \& Smith, C. A. "Group decision making: The impact of opportunity-cost time pressure and group support systems", Behavioral Research in Accounting, vol.12, pp.69, 2000.

[27] Dewi, N. M. N. R., \& Wirasedana, I. W. P. "Pengaruh time budget pressure, loc, dan task complexity pada dysfunctional audit behavior akuntan publik", E-Junal Akuntansi Universitas Udayana, vol.11, no.1, pp 1-14, 2015. Retrieved from https://www.e-jurnal.com/2015/07/pengaruh-time-budgetpressure-loc-dan.html

[28] Donnely, David P., Jeffrey J. Q., \& David O. “Auditor Acceptance of Dysfunctional Audit Behavior: An Explanatory Model Using Auditors' Personal Characteristics", Journal of Behavioral Research in Accounting. vol.15, pp.87-107, 2003. https://doi.org/10.23 08/bria.2003.15.1.87

[29] Hair Jr, J. F., Sarstedt, M., Hopkins, L., \& Kuppelwieser, V. G. "Partial least squares structural equation modeling (PLS-SEM): An emerging tool in business research", European business review, 2014. https://doi.org/10.1108/E BR-10-2013-0128

[30] Garson, G. D. "Partial least squares: regression and structural equation models", Asheboro, NC: Statistical Associates Publishers. 2016. http://www.statisticalassociat es.com/pls-sem.htm.

[31] Harmon, J. "The psychology of interpersonal relations", By Fritz Heider. New York: John Wiley and Sons, Inc., 1958.
322 pp. \$6.25. Social Forces, vol.37, no. 3, pp. 272-273, 1959. https://doi.org/10.2307/2572978

[32] Widyaningrum, T.,\& Sarwono, A. E. "Analisis sifat machiavellian dan pembelajaran etika terhadap sikap etis akuntan dan mahasiswa akuntansi", Jurnal Akuntansi dan Sistem Teknologi Informasi, vol. 9, no.1, 2012. http://ejurnal.unisri.ac.id/index.php/Akuntansi/article/view 1522

[33] Laras, S., \& Saud, I. M. "Pengaruh sifat machiavellian, karakter personal, dan kinerja Pegawai terhadap perilaku disfungsional auditor (studi empiris Pada perwakilan inspektorat di provinsi banten)", Jurnal REKSA: Rekayasa Keuangan, Syariah, dan Audit, vol.5, no.2, pp 67-86, 2018 http://www.journal2.uad.ac.id/index.php/reksa/article/view 1278

[34] Gosh, D., \& T, Crain. "Experimental investigation of ethical standards and perceived probability of audit on intentional noncompliance", Behavioral Research in Accounting. Vol.8, pp. 219-241, 1996. https://www.econbi z.de/Record/experimental-investigation-of-ethical-standard s-and-perceived-probability-of-audit-on-intentional-nonco mpliance-ghosh-dipankar/10007134342

[35] Chrismastuti, A. A., \& Purnamasari, V. "Dampak reinforcement contingency terhadap hubungan sifat machiavellian dan perkembangan moral", Simposium Nasional IX, Padang, 2006. Retrieved from https://smartaccounting.files.wordpress.com/2011/03/k-am en04.pdf

[36] Fadilasari, M. "Stres kerja sebagai pemoderasi pengaruh faktor independensi auditor, sifat machiavellian, dan emotional spiritual quotient (esq) terhadap perilaku disfungsional audit (Studi Empiris Pada Kantor Akuntan Publik di Kota Semarang) (Doctoral dissertation, Universitas Negeri Semarang), 2020. http://lib.unnes.ac.id 141793/1/7211415138.pdf

[37] Hartati, N. L. "Pengaruh karakteristik internal dan eksternal auditor terhadap penerimaan perilaku disfungsional atas prosedur audit”, Accounting Anlysis Journal, vol.1, no.2, 2012.

https://journal.unnes.ac.id/sju/index.php/aaj/article/view/6 54

[38] Devi, N. P. A., \& Ramantha, I. W. "Tekanan anggaran waktu, locus of control, sifat machiavellian, pelatihan auditor sebagai anteseden perilaku disfungsional auditor", E-Jurnal Akuntansi Universitas Udayana, vol.18, no.3, pp.2318-2345, 2017. https://ojs.unud.ac.id/index.php/Aku ntansi/article/view/26470

[39] Risanti, T. P., Aswar, K., Jumansyah, J., \& Wirman, W. "Determinants Influencing the Audit Quality: Empirical Evidence from Indonesia", Universal Journal of Accounting and Finance, vol.9, no.6, pp. 1265-1272, 2021. DOI: 10.13189/ujaf.2021.090607 